Al-Bayyinah: Journal of Islamic Law- ISSN: 1979-7486 (p); 2580-5088 (e) Volume VII Number 1, pp. 109- 124

\title{
STATUS PERWALIAN JANDA PASCA PERCERAIAN PERSPEKTIF HUKUM ISLAM DAN PERUNDANG- UNDANGAN DI INDONESIA
}

\section{Ahmad Nur \\ (Mahasiswa Program Doktor UIN Alauddin Makassar)}

\section{Abstract}

Guardians are the legal requirement for marriage, both guardians for widows and girls. Jurists have agreed to this, except for the Hanafi group. This is based on differences in the way the Qur'an and Hadiths are interpreted. Whereas in the legislation in force in Indonesia, the guardian becomes the legal requirement for marriage. If the marriage is carried out without a guardian, the marriage is deemed null and void and the relationship is considered adultery. This was exposed in Article 26 of Law No. 1 of 1974 and Article 19-23 of the Compilation of Islamic Law.

Kata Kunci: Status perwalian, perceraian, Hukum Islam, Perundang-undangan

\section{A. Latar Belakang}

Di Indonesia perkawinan sangat dipengaruhi oleh agama, budaya dan kehidupan sosial masyarakat. Hal ini tampak pada upacara perkawinan yang memiliki banyak ragam dan variasi. Penerapan adat atau aturan tertentu biasanya berkaitan dengan aturan atau hukum agama tertentu. Pengesahan secara hukum suatu perkawinan biasanya terjadi pada saat dokumen tertulis yang mencatatkan perkawinan ditandatangani. Salah satu aturan perkawinan yang berkaitan antara hukum agama dan hukum perundang-undangan di Indonesia yaitu Undang-Undang Nomor 1 Tahun 1974 Pasal 2 ayat 1 "Perkawinan adalah sah apabila dilakukan menurut 
hukum masing-masing agama dan kepercayaannya itu". Secara umum perkawinan di Indonesia telah diatur dalam Undangundang. Ketentuan tersebut ayat (1) sampai dengan ayat (5) Pasal berlaku sepanjang hukum masing-masing agamanya dan kepercayaannya itu dari yang bersangkutan tidak menentukan lain. $^{2}$

Secara umum, syarat-syarat perkawinan perkawinan di Indonesia telah diatur dalam Undang-Undang Nomor 1 Tahun 1974 khusus pada Pasal 6. Dalam pasal ini ditetapkan bahwa melangsungkan perkawinan seorang yang belum mencapai umur 21 (dua puluh satu) tahun harus mendapat izin kedua orang tua. Hal ini sesuai dengan Kompilasi Hukum Islam pada Bab IV Pasal 15 ayat (2) KHI yang berbunyi "Bagi calon mempelai yang belum mencapai umur 21 tahun harus mendapati izin sebagaimana yang diatur dalam Pasal 6 ayat (2),(3),(4) dan (5) UU No.1 Tahun 1974,3 Selain itu, pada Pasal 19 Kompilasi Hukum Islam, wali nikah dalam perkawinan merupakan rukun yang harus dipenuhi bagi calon mempelai wanita yang bertindak untuk menikahkan. ${ }^{4}$

Seorang perempuan yang hendak menikah disyaratkan harus ada wali, berarti tanpa wali nikah itu batal menurut hukum Islam atau nikahnya tidak sah. Wali nikah tersebut terdiri dari wali nasab dan wali hakim. Namun demikian, ditemukan adanya perbedaan mengenai status perwalian bagi seorang janda. Sebagaimana sabda Rasulullah saw.

$$
\text { الثيب ا حق بنفسها من وليها او لبكر يستا مر ها ابو ها. }
$$

${ }^{1}$ Zainal Abidin Abubakar, Peraturan Perundang-Undangan dalam Lingkungan Peradilan Agama,(Cet. III; Jakarta: Yayasan Al-Hikmah, 1993), h. 123.

${ }^{2}$ Zainal Abidin Abubakar, Peraturan Perundang-Undangan dalam Lingkungan Peradilan Agama, h. 125.

${ }^{3}$ Departemen Agama, Kompilasi Hukum Islam Di Indonesia (Jakarta: Direktorat Jenderal Pembinaan Kelembagaan Agama Islam, 1999), h.20.

${ }^{4}$ Departemen Agama, Kompilasi Hukum Islam Di Indonesia, h.20.

${ }^{5} \mathrm{Abu}$ 'Abd al-Rahman Ahmad bin Syu'aib al-Nasaiy, Jilid III (Beirut Libanon: Dar al-Fikr, 1980), h. 85. 
Artinya:

"Perempuan Janda lebih berhak terhadap dirinya daripada walinya, sedangkan anak perawan dikawinkan oleh bapaknya”. (Hadist Riwayat Dawud).

Hadits ini menyatakan bahwa ada keistimewaan hak yang disandang oleh seorang janda mengenai status perwaliannya pasca perceraian. Sehubungan dengan hal tersebut, perlu penelitian lebih lanjut mengenai hak dari seorang janda dalam hal perwalian dan bagaimana aturan dalam hukum Islam maupun Perundang-Undangan di Indonesia mengenai hal itu.

\section{B. Rumusan Masalah}

Berdasarkan latar belakang masalah yang di atas, diuraikan beberapa rumusan masalah sebagai berikut:

1. Bagaimana status perwalian janda pasca perceraian menurut Fikih Klasik?

2. Bagaimana status perwalian seorang janda pasca perceraian menurut Perundang-undangan di Indonesia?

C. Tujuan dan Kegunaan Penelitian

Berdasarkan rumusan masalah, maka penelitian ini bertujuan:

1. Untuk mengetahui status perwalian janda pasca perceraian ditinjau dari fikih klasik.

2. Untuk mengetahui status perwalian seorang janda pasca perceraian ditinjau dari Undang-undang Nomor 1 Tahun 1974 dan Kompilasi Hukum Islam (KHI).

Adapun kegunaan dari penelitian ini, yaitu:

1. Sebagai bahan rujukan membandingkan implikasi antara sumber hukum Islam dan Perundang-Undangan di Indonesia terhadap status perwalian janda pasca perceraian.

2. Memberi tawaran konsep dari hasil telaah pustaka mengenai status perwalian janda pasca perceraian.

\section{Metodologi Penelitian}

Penelitian ini menggunakan jenis penelitian kepustakaan yang menggunakan data sekunder yang bersumber dari 3 bahan hukum, yaitu: 
1. Bahan hukum primer, melipti: Undang-Undang Nomor 1 Tahun 1974 Tentang Perkawinan, PP. No. 9 Tahun 1975 tentang pelaksanaan UU No. 1 Tahun 1974, dan Kompilasi Hukum Islam (KHI).

2. Bahan hukum sekunder, yakni kitab-kitab fikih atau pendapat para ulama tentang perwalian, khususnya perwalian seorang janda serta literatur yang mempunyai relevansi dengan pembahasan.

3. Bahan hukum tersier, meliputi kamus dan ensiklopedia.

Penelitian ini mengunakan metode pendekatan yuridis dan pendekatan konseptual. Cara pengolahan bahan hukum dilakukan secara induktif. Selanjutnya bahan hukum yang ada dianalisisi secara deskriptif yang diawali dengan mengelompokkan bahan hukum yang sama menurut sub bab. Selanjutnya dilakukan analisis keseluruhan aspek untuk memahami makna hubungan antara aspek yang satu dengan yang lainnya dan dengan keseluruhan aspek yang menjadi pokok permasalahan penelitian yang dilakukan secara induktif sehingga memberi gambaran hasil secara utuh.

\section{E. Hasil Pembahasan}

\section{Konsep Dasar Perwalian}

Wali berasal dari bahasa Arab yaitu isim fa'il, masdarnya adalah الولاية wilayah. Kata wilayah secara etimologi berarti al-sultah ( kekuasaan) dan al-qudrah (kemampuan). Karena itu wali berarti shahibul al-sultan (yang mempunyai kekuasaan dan kemampuan). ${ }^{6}$ Jadi wali adalah pemilik kekuasaan yang berlaku terhadap akad yang di kehendakinya." Secara etimologis, "wali" mempunyai arti pelindung, penolong atau penguasa. Adapun yang dimaksud wali dalam pembahasan ini adalah wali dalam pernikahan, yaitu seseorang yang bertindak atas nama mempelai perempuan dalam suatu akad nikah. Akad nikah dilakukan oleh dua pihak yaitu pihak laki-laki yang

${ }^{6}$ Abd Wahbah al-Zuhayly, Al-Fiqh Al-Islam wa Adillatuhu, Juz VII, (Cet. III; Damaskus: Dar Fikr, 1409 H/1898 M), h. 669.

${ }^{7}$ Syarifuddin Latif, Hukum Perkawinan di Indonesia (Buku I), (Cet.1; t,t: CV. Berkah Utami, 2010), h. 74 . 
dilakukan oleh mempelai laki-laki itu sendiri dan pihak perempuan yang dilakukan oleh walinya. ${ }^{8}$

Dasar hukum perwalian diatur dalam Undang-Undang Nomor 1 Tahun 1974 Bab XI Pasal 50 dan Pasal 51 yang berbunyi:

\section{Pasal 50}

(1) Anak yang belum mencapai umur 18 (delapan belas) tahun atau belum pernah melakukan perkawinan, yang tidak berada dibawah kekuasaan orang tua, berada dibawah kekuasaan wali.

(2) Perwalian itu mengenai pribadi anak yang bersangkutan maupun harta bendanya.

\section{Pasal 51}

(1) Wali dapat ditunjuk oleh satu orang tua yang menjalankan kekuasaan orang tua sebelum ia meninggal, dengan surat wasiat atau dengan lisan dihadapan 2 (dua) orang saksi.

(2) Wali sedapat-dapatnya diambil dari keluarga anak tersebut atau orang lain yang sudah dewasa, berfikiran sehat, adil, jujur dan berkelakuan baik.

(3) Wali wajib mengurus anak yang dibawah penguasaannya dan harta bendanya sebaik-baiknya dengan menghormati agama dan kepercayaan itu. ${ }^{9}$

Perwalian juga diatur dalam Kompilasi Hukum Islam (KHI) Pasal 19 sampai dengan pasal 23. Adapun dasar hukum dari wali itu sendiri adalah hadist yang diriwayatkan oleh Tirmidzi:

$$
\text { ايما إمر ةأ نكحت بغيرنذإوليها فنكا حها نا طل. } 10
$$

Artinya:

"Barang siapa di antara perempuan yang menikah tanpa izin walinya, maka pernikahannya batal." (HR. Tirmidzi).

Begitupun hadis dari Aisyah ra. Berikut:

${ }^{8}$ Amir Syarifuddin, Garis-Garis Besar Fiqih (Ed. 1; Cet. II; Jakarta: Prenada Media, 2005), h. 90.

${ }^{9}$ Zainal Abidin Abubakar, Peraturan Perundang-Undangan dalam Lingkungan Peradilan Agama, h. 134-135.

${ }^{10} \mathrm{Abu}$ 'Isa Muhammad bin 'Isa bin Sauurat al-Turmuzy, Al-Jami' alShahih, Jilid III, (Dar al-Fikr: Beirut Libanon, 1988), h. 407. 


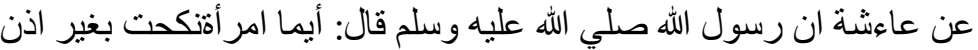
وليها فنكاحها باطل, فنكاحها بأطل, فنكاحها باطل...... 11

Artinya:

"Aisyah berkata, Rasulullah SAW. Bersabda, "siapa pun wanita yang menikah tanpa izin walinya, maka nikahnya itu batal (diucapkan tiga kali)."

Ada beberapa macam jenis-jenis perwalian, yakni:

a. Wali nasab, yaitu anggota keluarga yang berasal dari keluarga mempelai perempuan yang mempunyai hubungan darah dari pihak ayahnya, saudara laki-laki sekandung dan seayah, kemenakan laki-laki, sekandung dan seayah. ${ }^{12}$

b. Wali hakim adalah wali nikah yang diambil dari hakim (pejabat pengadilan atau aparat KUA atau PPN) atau penguasa dari pemerintah. ${ }^{13}$

c. Wali tahkim adalah wali yang diangkat oleh calon suami dan atau calon isteri.

d. Wali maula adalah wali yang menikahkan budaknya, atau majikannya sendiri.

e. Wali mujbir dan wali adhol. Wali mujbir adalah wali bagi orang yang kehilangan kemampuannya seperti orang gila, belum mencapai umur, mumayyiz termasuk di dalamnya perempuan yang masih gadis. ${ }^{14}$ Sedangkan wali adhol adalah wali yang enggan atau menolak. Maksudnya seorang wali yang enggan atau menolak tidak mau dinikahkan atau tidak mau menjadi wali dalam perkawinan anak perempuannya dengan seorang laki-laki yang sudah menjadi pilihan anaknya karena sesuatu hal. ${ }^{15}$

${ }^{11} \mathrm{Abu}$ 'Isa Muhammad bin 'Isa bin Sauurat al-Turmuzy, Al-Jami' alShahih, h. 408 .

${ }^{12}$ Sayyid Sabiq, Al-Fiqh Al-Sunnah, Jilid I (Cet VIII; Beirut: Dar alKitab Al-Arabiy, 1407 H/1987 M), h. 123.

${ }^{13}$ Beni Ahmad Saebani, Fikih Munakahat (Cet. I; Bandung: CV Pustaka Setia, 2001), h. 249.

${ }^{14}$ Beni Ahmad Saebani, Fikih Munakahat, h. 252.

${ }^{15}$ Syarifuddin Latif, Hukum perkawinan di Indonesia, h. 24. 
Ulama mazhab sepakat bahwa wali dan orang-orang yang menerima wasiat untuk menjadi wali, dipersyaratkan harus baliq, mengerti, dan seagama, bahkan banyak di antara mereka yang mensyaratkan bahwa wali itu harus adil, sekalipun ayah dan kakek. Adapun syarat perwalian menurut Syarifuddin Latif, yakni berakal, baliq, Islam, lakilaki, adil, orang fasik tidak sah menjadi wali, ${ }^{16}$ merdeka, tidak dipaksa menjadi wali, cakap, tidak cacat penglihatannya, mahram dari perempuan yang bersangkutan, dan tidak sedang ihram. ${ }^{17}$ Selain itu, para fuqaha sepakat bahwa sifat-sifat seorang wali adalah Islam, dewasa dan laki-laki. ${ }^{18}$

Jumhur ulama membagi wali itu kepada dua kelompok, yaitu:

a. Wali dekat atau wali qarib ( الولنالقر يب), yaitu ayah dan kalu tidak ada ayah pindah kepada kakek.

b. Wali jauh atau wali ab’ad (الو لى الا بعد). Yang menjadi wali jauh ini secara berurutan adalah:

1. Saudara laki-laki kandung, kalau tidak ada pindah kepada

2. Saudara laki-laki seayah, kalau tidak ada pindah kepada

3. Anak saudara laki-laki kandung, kalau tidak ada pindah kepada

4. Anak saudara laki-laki seayah, kalau tidak ada pindah kepada

5. Paman kandung, kalau tidak ada pindah kepada

6. Paman seayah, kalau tidak ada pindah kepada

7. Anak paman kandung, kalau tidak ada pindah kepada

8. Ayah paman seayah.

9. Ahli waris kerabat lainnya kalau ada.

10. Sultan atau wali hakim yang memegang wilayah umum. ${ }^{19}$

\footnotetext{
${ }^{16}$ Syarifuddin Latif, Hukum perkawinan di Indonesia, h. 24.

${ }^{17}$ Syarifuddin Latif, Hukum perkawinan di Indonesia, h. 79

${ }^{18}$ Beni Ahmad Saebani, Fikih Munakahat, h. 253.

${ }^{19}$ Amir Syarifuddin, Garis-Garis Besar Fiqih, h. 92.
} 


\section{Konsep Dasar Perceraian}

Dalam KHI pada Pasal 113 menyatakan perceraian merupakan salah satu sebab putusnya perkawinan. ${ }^{20}$ Menurut Abu Zakaria Al-Anshari, talak adalah melepaskan tali akad nikah dengan kata talak dan semacamnya. Jadi talak adalah menghilangkan ikatan perkawinan sehingga setelah hilangnya ikatan perkawinan itu isteri tidak lagi halal bagi suaminya. ${ }^{21}$ Sedangkan, cerai talak adalah cerai yang dijatuhkan oleh suami terhadap isterinya, sehingga perkawinan mereka menjadi putus. Sedangkan cerai gugat adalah cerai yang didasarkan atas adanya gugatan yang diajukan oleh isteri, agar perkawinan dengan suaminya menjadi putus.

Syarifuddin latif membagi bentuk bentuk perceraian sebagai berikut:

a. Khulu' adalah perceraian antara suami isteri walaupun memakai lafadz penebusan dengan ganti yang tertentu yang kembali kepada pihak suami.

b. Fasakh adalah membatalkan akad, dan melepaskan tali ikatan perkawinan suami isteri.

c. Zihar adalah suami menyamakan isterinya yang idak di thalaq ba'in dengan perempuan yang haram di nikahiya.

d. Ila' adalah sumpah tidak mau mencampuri isteri dengan bersumpah.

e. Li'an, diambil dari kata tsulasi mujarrad "al-la'nu" (kutukan), karena sesungguhnya suami mengucapkan pada kali yang ke lima setelah bersumpah, "kutukan Allah atasnya jika ia termasuk orang-orang yang berdusta". Mengenai kutukan itu, bisa diungkapkan dengan istilah li'an dan mula'ana",22

Dalam al-Qur'an tidak terdapat ayat-ayat yang menyuruh atau melarang eksistensi perceraian itu. Meskipun banyak ayat al-Qur'an yang mengatur talak tetapi isinya hanya

${ }^{20}$ Tim Permata Press, Kompilasi Hukum Islam (KHI), (t.c.; t.t.: Permata Pres, t.th), h. 35.

${ }^{21}$ Timahi dan Sohari Sahrani, Fikih Munakahat Kajian Fikih Nikah Lengkap (Cet. II; Jakarta: PT. Rajagrafindo Persada, 2010), h. 230.

${ }^{22}$ Syarifuddin Latif, Hukum perkawinan di Indonesia, h.63. 
sekedar mengatur bila talak itu terjadi. Salah satu firman Allah swt dalam surah At-Thalaq ayat 1:



Terjemahnya:

"Hai Nabi, apabila kamu menceraikan istri-istrimu maka hendaklah kamu ceraikan mereka pada waktu mereka dapat (menghadapi) iddahnya (yang wajar) dan hitunglah waktu iddah itu serta bertakwalah kepada Allah tuhanmu. Janganlah kamu keluarkan mereka dari rumah mereka dan janganlah mereka (diizinkan) keluar kecuali mereka mengerjakan perbuatan keji yang terang. Itulah hukumhukum Allah dan barang siapa yang melanggar hukumhukum Allah, maka sesungguhnya dia telah berbuat zalim terhadap dirinya sendiri. Kamu tidak mengetahui barangkali Allah mengadakan sesudah itu sesuatu hal yang baru." (QS. At-Thalaq ayat 1$).^{23}$

Tentang hukum perceraian ini, para ahli fikih berbeda pendapat. Hanafi dan Hambali mengatakan "terlarang", kecuali karena alasan yang benar. Perceraian ini juga diatur dalam Kompilasi Hukum Islam (KHI) Pasal 114 "Putusnya perkawinan yang disebabkan karena perceraian dapat terjadi karena talak atau berdasarkan gugatan perceraian".

Akad nikah menimbulkan hak dan tanggung jawab secara bersama, yaitu:

a. Suami dan isteri di halalkan mengadakan hubungan seksual.

b. Haram melakukan pernikahan.

c. Dengan adanya ikatan perkawinan, kedua belah pihak saling mewarisi apabila salah seorang di antara keduanya telah meninggal meskipun belum bersetubuh.

d. Anak mempunyai asap yang jelas.

e. Kedua pihak wajib bertingkah laku dengan baik sehingga dapat melahirkan kemesraan kedamaian hidup. ${ }^{24}$

${ }^{23}$ Departemen Agama RI, Al-Qur'an dan Terjemahannya, (t.c.; Jakarta: CV.Darul Sunnah, 2007), h. 559

${ }^{24}$ Timahi dan Sohari Sahrani , Fikih Munakahat Kajian Fikih Nikah Lengkap, h. 157. 
Adapun kewajiban suami isteri, yaitu:

a. Mempergauli isteri dengan baik

b. Menjaga dengan baik

c. Suami datangi isterinya

d. Menjaga rahasia masing-masing.

Dengan demikian, laki-laki dan perempuan mempunyai hak dan kewajiban yang sama. Salah satu prinsip yang dianut dalam penetapan pasal-pasal tentang hak dan kewajiban suami dan isteri adalah untuk menaikkan serajat perempuan sehingga perempuan perlu mendapatkan perlindungan yang kongkrit melalui undang-undang.

3. Status Perwalian Janda Pasca Perceraian Perspektif Hukum Islam dan Perundang-Undangan Di Indonesia

a. Status Perwalian Janda Pasca Perceraian Menurut Fikih Klasik (Al-Qur'an dan Hadist)

Ulama Malikiyah, menyatakan bahwa rukun perkawinan adalah; 1) wali, 2) mahar, 3) calon mempelai laki-laki, 4) calon mempelai perempuan, 5) sigat. $^{25}$ Menurut Ulama Syafi'iyah, rukun perkawinan adalah; 1) calon mempelai laki-laki, 2) calon mempelai perempuan, 3) wali, 4) dua orang saksi, 5) sigat. ${ }^{26}$ Sedangkan Ulama Hanafiyah, rukun perkawinan adalah; 1) calon mempelai laki-laki, 2) calon mempelai perempuan, 3) dua orang saksi, 4) sigat, 5) ijab-qabul. ${ }^{27}$

Para fuqaha berbeda pendapat dalam masalah wali, apakah menjadi syarat sahnya pernikahan atau tidak. Imam Malik berpendapat bahwa tidak ada pernikahan tanpa wali, dan wali merupakan syarat sahnya pernikahan. Pendapat ini juga dikemukakan oleh Imam Syafi'i. ${ }^{28}$ Imam Abu Hanifah, Zufar, Asy-Sya'bi, dan Az-Zuhri berpendapat bahwa apabila seorang wanita melakukan akad nikah tanpa

${ }^{25}$ Abd. Al-Rahman al-Jaziriy, Kitab al-fiqhu 'Ala al-Mazahib alArba'ah, Juz IV (t.c.; Mesir: al-Maktab al-Tijariyah al-Kubra, 1969), h. 12.

${ }^{26}$ Abd. Al-Rahman al-Jaziriy, Kitab al-fiqhu 'Ala al-Mazahib alArba'ah, h. 12.

27 Abd. Al-Rahman al-Jaziriy, Kitab al-fiqhu 'Ala al-Mazahib alArba'ah, h. 13.

${ }^{28}$ Slamet Abidin dan Aminuddin, Fikih Munakahat, Jilid II (t.c.; Bandung: Pustaka Setia, 1999), h. 84. 
wali sedang calon suaminya sepadan, pernikahannya boleh. $^{29}$

Abu Dawud memisahkan antara gadis dan janda dengan syarat adanya wali pada gadis dan tidak mensyaratkan keberadaan wali kepada janda. ${ }^{30}$ Pendapat lain juga mengatakan bahwa persyaratan wali itu hukumnya sunnah bukan fardhu karena mereka berpendapat, adanya waris mewarisi antara suami dan isteri yang perkawinannya terjadi tanpa menggunakan wali, dan juga wanita terhormat boleh mewakili kepada seorang lakilaki untuk menikahkannya. ${ }^{31}$ Imam Malik menganjurkan agar seorang janda mengajukan walinya untuk menikahkannya. ${ }^{32}$ Sementara, Maliki dari Bagdad yang mengatakan bahwa wali itu termasuk syarat sahnya pernikahan bukan kelengkapan pernikahan. ${ }^{33}$

Dasar hukum bahwa wali merupakan syarat sahnya pernikahan adalah dalam surah Al-Baqarah ayat 234 yang berbunyi:

Terjemahnya:

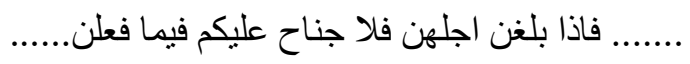

".....kemudian apabila telah habis masa iddahnya, maka tiada dosa bagimu (para wali) membiarkan mereka berbuat terhadap istri mereka..." (Q.S.AL-baqarah:234). ${ }^{34}$

Menurut Malik, surah Al-Baqarah ayat 234 itu ditujukan kepada para wali, jika mereka tidak mempunyai hak dalam perwalian, tentu mereka tidak dilarang untuk menghalang-halangi. ${ }^{35}$ Para ulama penganut mazhab Hanafi mengemukakan bahwa seorang wanita boleh melakukan akad pernikahan sendiri, sebagaimana ia boleh melakukan berbagai hal seperti akad jual beli, sewa menyewa, gadai dan sebagainya

${ }^{29}$ Slamet Abidin dan Aminuddin, Fikih Munakahat, h. 84.

${ }^{30}$ Beni Ahmad Saebani, Fikih Munakahat, h. 117.

${ }^{31}$ Beni Ahmad Saebani, Fikih Munakahat, h. 117.

${ }^{32}$ Beni Ahmad Saebani, Fikih Munakahat, h. 117.

${ }^{33}$ Beni Ahmad Saebani, Fikih Munakahat, h. 117.

${ }^{34}$ Departemen Agama RI, Al-Qur'an dan Terjemahannya, h. 39.

${ }^{35}$ Timahi dan Sohari Sahrani, Fikih Munakahat Kajian Fikih Nikah Lengkap, h. 92. 
yang memang tidak ada bedanya dengan akad nikah ${ }^{36}$ Sedangkan, Imam Malik mengatakan bahwa perkawinan tanpa wali boleh dilakukan bagi wanita yang hina dan tidak dilakukan oleh wanita yang mulia. Sedangkan mazhab Zhahiriyah menyebutkan bahwa perkawinan tanpa wali boleh dilakukan oleh janda, tetapi tidak dibolehkan bagi seorang gadis. ${ }^{37}$

Mengenai perwalian seorang janda, terdapat banyak perbedaan pendapat. Perbedaan pendapat itu di dasari oleh cara pandang dan penafsiran yang berbeda. Jumhur ulama (Syafi'i, Ahmad bin Hambal dan Malik) berpendapat bahwa harus ada wali dalam perkawinan. Seorang wanita yang akan melangsungkan perkawinan harus menunjuk seorang wali untuk mengawinkannya. ${ }^{38}$ Sedangkan Abu Hanifah, Abu Yusuf, Zuhar, Imamiyah, Al-Sya'biy, Zuhri dan Daud berpendapat bahwa wali dalam perkawinan hanya disyariatkan kepada wanita yang belum dewasa saja. Jadi wanita yang sudah dewasa dan janda boleh mengawinkan dirinya sendiri. ${ }^{39}$ Mereka beranggapan bahwa wali bukan rukun perkawinan.

\section{b. Status Perwalian Janda Pasca Perceraian Menurut Perundang-Undangan Di Indonesia}

Berbeda dengan Kompilasi Hukum Islam, Undangundang Nomor 1 Tahun 1974 tentang perkawinan memberikan peranan yang sangat menentukan sah atau tidaknya suatu perkawinan kepada hukum negara, agama dan kepercayaan masing-masing calon mempelai secara administrasi. Secara adminitrasi, perkawinan yang akan dilangsungkan mesti diketahui oleh keluarganya khususnya wali dari wanita yang akan menikah, agar nantinya perkawinan yang telah dilaksanakan sah menurut hukum negara dan hukum agama kepercayaan masing-masing.

Mengenai wali nikah baik seorang janda atau gadis secara jelas tertulis dalam Pasal 26 ayat 1 undang-undang nomor 1 tahun 1974 tentang perkawinan yang berbunyi :

\footnotetext{
${ }^{36}$ Syaih Hasan Ayyub, Fikih Keluarga (Cet.VI; Jakarta: Pustaka alKautsar, 2009), h. 78.

${ }^{37}$ Syaih Hasan Ayyub, Fikih Keluarga, h. 80.

${ }^{38}$ Syarifuddin Latif, Fikih Problematik, (Cet. II; Jakarta: Gaung Persada, 2015), h. 87.

${ }^{39}$ Syarifuddin Latif, Fikih Problematik, h. 87.
} 
"Perkawinan yang dilangsungkan dimuka pegawai pencatat perkawinan yang tidak berwenang, wali nikah yang tidak sah atau yang dilangsungkan tanpa dihadiri oleh 2 (dua) orang saksi dapat dimintakan pembatalannya oleh keluarga dalam garis keturunan lurus ke atas dari suami atau isteri, jaksa dan suami atau isteri."

Sama halnya dengan UU Nomor 1 Tahun 1974, Kompilasi Hukum Islam juga tidak mengatur secara terperinci tentang perwalian seorang janda maupun gadis. Kompilasi Hukum Islam hanya mengatur tentang wali nikah secara umum. Ada beberapa pasal yang mengatur tentang wali tersebut, yakni pasal 19 sampai dengan pasal 23. Ada beberapa pasal yang mengatur tentang wali tersebut, yakni pasal 19 sampai dengan pasal 23.

\section{Pasal 19}

Wali nikah dalam perkawinan merupakan rukun yang harus dipenuhi bagi calon mempelai wanita yang bertindak untuk menikahkan.

\section{Pasal 20}

1) Yang bertindak sebagai wali nikah ialah seorang laki-laki yang memenuhi syarat hukum Islam yakni muslim, aqil dan baligh.

2) Wali nikah terdiri dari :

a. Wali nasab;

b. Wali hakim.

\section{Pasal 21}

1) Wali nasab terdiri dari empat kelompok dalam urutan kedudukan, kelompok yang satu didahulukan dan kelompok yang lain sesuai erat tidaknya susunan kekerabatan dengan calon mempelai wanita.

Pertama, kelompok kerabat laki-laki garis lurus keatas yakni ayah, kakek dari pihak ayah dan seterusnya.

Kedua, kelompok kerabat saudara laki-laki kandung atau saudara laki-laki seayah, dan keturunan laki-laki mereka.

${ }^{40}$ Zainal Abidin Abubakar, Peraturan Perundang-Undangan Dalam h. 129. 
Ketiga, kelompok kerabat paman, yakni saudara laki-laki kandung ayah, saudara seayah dan keturunan laki-laki mereka.

Keempat, kelompok saudara laki-laki kandung kakek, saudara laki-laki seayah dan keturunan laki-laki mereka.

2) Apabila dalam satu kelompok wali nikah terdapat beberapa orang yang sama-sama berhak menjadi wali, maka yang paling berhak menjadi wali ialah yang lebih dekat derajat kekerabatannya dengan calon mempelai wanita.

3) Apabila dalam satu kelompok sama derajat kekerabatan aka yang paling berhak menjadi wali nikah ialah kerabat kandung dari kerabat yang seayah.

4) Apabila dalam satu kelompok, derajat kekerabatannya sama yakni sama-sama derajat kandung atau sama-sama dengan kerabat seayah, mereka sama-sama berhak menjadi wali nikah, dengan mengutamakan yang lebih tua dan memenuhi syarat-syarat wali.

\section{Pasal 22}

Apabila wali nikah yang paling berhak, urutannya tidak memenuhi syarat sebagai wali nikah atau oleh karena wali nikah itu menderita tuna wicara, tuna rungu atau sudah udzur, maka hak menjadi wali bergeser kepada wali nikah yang lain menurut derajat berikutnya.

\section{Pasal 23}

1) Wali hakim baru dapat bertindak sebagai wali nikah apabila wali nasab tidak ada atau tidak mungkin menghadirkannya atau tidak diketahui tempat tinggalnya atau gaib atau adlal atau enggan.

2) Dalam hal wali adlal atau enggan maka wali hakim baru dapat bertindak sebagai wali nikah setelah ada putusan pengadilan Agama tentang wali tersebut. ${ }^{41}$

Dengan demikian, pada dasarnya tidak adanya perbedaan antara hukum Islam (KHI) dan Undang-undang Nomor 1 Tahun 1974 tentang perkawinan. Keduanya tidak mengatur secara rinci antara wali perkawinan gadis maupun janda. Di dalam KHI maupun Undang-Undang Nomor 1 Tahun 1974 menetapkan wali sebagai rukun perkawinan. Jadi di

${ }^{41}$ Tim Permata Press, Kompilasi Hukum Islam (KHI), h. 6-8. 
Indonesia, apabila seorang wanita yang telah berstatus janda akan melangsungkan perkawinan, tetap harus menunjuk seorang wali untuk menikahkannya dan apabila ia menikahkan dirinya sendiri maka nikahnya dianggap batal sebagaiman yang tercantum dalan Pasal 26 ayat 1 UU No. 1 Tahun 1974 Tentang Perkawinan.

\section{F. Penutup}

Adapun simpulan yang dapat diambil dari pembahasan ini sebagai berikut:

1. Mengenai perwalian janda pasca perceraian, terjadi perbedaan pendapat antara jumhur ulama. Golongan pertama yang mengharuskan adanya wali dalam perkawinan baik itu perkawinan yang dilakukan oleh seorang janda maupun gadis yang dianut oleh Imam Syafi'i, Malik, dan Ahmad bin Hambal. Golongan ini mengatakan bahwa tidak sah perkawinan tanpa seorang wali. Sedangkan golongan yang kedua mengatakan, wali nikah hanya berlaku pada wanita yang belum dewasa, budak, dan tidak cakap hukum, sedangkan wanita yang telah dewasa, merdeka, serta seorang janda status walinya hanyalah sunnah saja.

2. Di Indonesia, hukum yang menjadi acuan dalam perkawinan adalah KHI dan UU No. 1 Tahun 1974 Tentang perkawinan. Namun mengenai status perwalian seorang janda pasca perceraian tidak diatur secara mendasar. Di dalam KHI maupun UU No. 1 Tahun 1974 dikatakan bahwa tidak sah nikah yang dilakukan tanpa adanya wali baik itu perkawinan yang dilakukan oleh janda maupun oleh gadis. 


\section{G. Daftar Pustaka}

Abidin, Slamet dan Aminuddin. Fikih Munakahat. Jilid II. t.c.; Bandung: Pustaka Setia, 1999.

Abubakar, Zainal Abidin. Peraturan Perundang-Undangan dalam Lingkungan Peradilan Agama. Cet. III; Jakarta: Yayasan Al-Hikmah, 1993.

Ayyub, Syaih Hasan. Fikih Keluarga. Cet.VI; Jakarta: Pustaka al-Kautsar, 2009.

Departemen Agama RI. Al-Qur'an dan Terjemahannya. t.c.; Jakarta: CV.Darul Sunnah, 2007.

Departemen Agama. Kompilasi Hukum Islam Di Indonesia. Jakarta: Direktorat Jenderal Pembinaan Kelembagaan Agama Islam, 1999.

al-Jaziriy, Abd. Al-Rahman. Kitab al-fiqhu 'Ala al-Mazahib alArba'ah, Juz IV. t.c.; Mesir: al-Maktab al-Tijariyah alKubra, 1969.

Latif, Syarifuddin. Hukum Perkawinan di Indonesia (Buku I).Cet.1; t,t: CV. Berkah Utami, 2010.

—. Fikih Problematik. Cet. II; Jakarta: Gaung Persada, 2015.

Sabiq, Sayyid. Al-Fiqh Al-Sunnah. Jilid I. Cet VIII; Beirut: Dar al-Kitab Al-Arabiy, $1407 \mathrm{H} / 1987 \mathrm{M}$.

Saebani, Beni Ahmad. Fikih Munakahat. Cet. I; Bandung: CV Pustaka Setia, 2001.

Syarifuddin, Amir. Garis-Garis Besar Fiqih. Ed. 1; Cet. II; Jakarta: Prenada Media, 2005.

Timahi dan Sohari Sahrani. Fikih Munakahat Kajian Fikih Nikah Lengkap. Cet. II; Jakarta: PT. Rajagrafindo Persada, 2010.

Tim Permata Press. Kompilasi Hukum Islam (KHI). t.c.; t.t.: Permata Pres, t.th.

al-Turmuzy, Abu 'Isa Muhammad bin 'Isa bin Sauurat. AlJami' al-Shahih. Jilid III. Dar al-Fikr: Beirut Libanon, 1988.

al-Zuhayly, Abd Wahbah. Al-Fiqh Al-Islam wa Adillatuhu. Juz VII. Cet. III; Damaskus: Dar Fikr, 1409 H/1898 M. 